\title{
REGIONAL BUSINESS CYCLES IN POLAND
}

\author{
Joanna SPYCHAŁA \\ Poznań University of Economics and Business, Poznań; joanna.spychala@ue.poznan.pl, \\ ORCID: 0000-0002-0706-4205
}

Purpose: The main goal of the considerations presented hereinbelow is a presentation of the course of action as well as an analysis of crucial features of cyclical fluctuations differentiated as entities in the Polish economy as well as in all provinces in the period of the first quarter of 2005 until the second quarter of 2019 based on the rate of the sold production of industry.

Design/methodology/approach: A share of the respective regions in the structure of the sold production of industry was assessed. Finally, an attempt of assessing the rate of convergence in terms of morphology of a national chain with time chains of the respective regions was undertaken. In the thesis, a hypothesis is being stated that the most synchronised with the cycle of Poland are regions having the biggest share in the sold production of industry. Methodological bases of the research process as well as an empirical assessment of the regional business cycles in Poland were preceded by theoretical analyses concerning the notion, the core as well as the morphological features of the regional business fluctuations.

Findings: Making an assessment of the progression of business cycle fluctuations of the economy of Poland as a whole as well as business cycle fluctuations of Polish provinces in the period between the first quarter 2005 and the second quarter of 2019, one may conclude the progression is not uniform. The variation depends to a large extent on the specificity of development of each region. Provinces which have a lower share in the national structure of the sold production of industry demonstrate higher sensitivity to economic shocks. The highest degree of compliance with the national cycle has been demonstrated in provinces with the highest rate of share in the structure of the sold production of industry.

Research limitations/implications: The conducted research, as well as the obtained results might thus be a basis for taking up more extensive analyses in that field, comprising a discussion on the remaining morphological features of business cycles.

Originality/value: Determining the course of cyclical fluctuations in Poland as well as in its respective provinces has been made.

Keywords: business cycles, cycle synchronization, region.

Category of the paper: Research paper. 


\section{Introduction}

The issue of regional business cycles has been growing in importance against the background of the relevance and efficiency of the economic policy managed. Cyclical fluctuations have been an inseparable part of the functioning of both developed and developing countries. The understanding of the phenomenon of the cyclical character of the phenomenon is crucial for the understanding of the management of the economic policy, therefore the issues concerning cyclical fluctuations are an area of interest of contemporary economists (Spychała, 2015).

Apart from theoretical considerations, the analyses of the economic business cycles should also contain analytical works conducted based on empirical data characterising phenomena and processes existent in the economic activity. The need for renewing the verification in that respect is natural in case of tools used in empirical research concerning phenomena of differing categories of courses of action cyclical fluctuations fall under. Therefore, in the following article, apart from theoretical and methodological issues concerning the diagnosing of contemporary cyclical fluctuations, an attempt to specify the course of cyclical fluctuations in Poland as well as in its respective provinces has been made.

The main goal of the considerations presented hereinbelow is a presentation of the course of action as well as an analysis of crucial features of cyclical fluctuations differentiated as entities in the Polish economy as well as in all provinces in the period of the first quarter of 2005 until the second quarter of 2019 based on the rate of the sold production of industry. A share of the respective regions in the structure of the sold production of industry was assessed. Finally, an attempt of assessing the rate of convergence in terms of morphology of a national chain with time chains of the respective regions was undertaken. In the thesis, a hypothesis is being stated that the most synchronised with the cycle of Poland are regions having the biggest share in the sold production of industry.

\section{Concepts of the regional fluctuations of the cycle}

A cyclical character is strictly related to the process of the socio-economic development, and the course of action of cyclical fluctuations depends on the level of development achieved by a particular economic area. In the circumstances of deepening development disproportions of not only states but also regions, one may assume the image of the progression of economic fluctuations on the national scale is a resultant of the changes occurring in the regions (Warżała, 2016). Booming regions with a significant variation in the structure of the economy are considered to be more immune to economic crises. Regions characterised by a less varied 
economic structure, and at the same time, a lower level and speed of development, are experiencing changes in the cycles in a more rapid manner (Niemira, and Klein, 1994). Bearing this in mind, getting to know the pattern of the progression as well as the morphological discrepancies of the regional business cycles towards the changes on the national level allows for counteracting the negative effects related to the specific course of action of the changes in the economic activity, characterising particular regions (Warżała, 2016).

In source literature, there are two trends of thought within the scope of the international and interregional effects of the widening economic integration. The beginning of the division was initiated by the results of the research on the effects of uniform monetary policy within the common currency area in the regional dimension. As a result of those considerations, contemporarily in source literature, the issue of cyclical fluctuations in the regional aspect is approached in two ways. The first concept stems from Paul Krugman's analysis (1991), which compared the regions of the European Union to the regions of the United States. P. Krugman assumed the result of introducing a single currency area might be an increase in the level of convergence of cyclical cycles on the level of states, with a simultaneous increase in the scope of divergence on the level of regions. Drawing conclusions, he expressed a conviction that economic integration signifies an increase in the regional concentration of industrial activity, increasing the probability of asymmetrical shocks and divergent cyclical cycles (Krugman, 1991; Camacho, Perez-Quiros, and Saiz, 2008; Warżała, 2014). The second concept suggested by Jeffrey Frankel and Andrew Rose (1998) assumes that alongside a deepening economic integration, symmetrical changes take place, leading to more synchronised business cycles in the national and regional perspective. According to that concept, as a result of eliminating economic barriers between countries and regions of one currency area, there is an intensification of trade exchange. A direct result of that process has been considered an increase in the level of synchronicity of cyclical fluctuations. J. Frankel and A. Rose have indicated the management of a common economic area on the area being integrated as an additional factor contributing to the synchronisation of business cycles (Frankel, and Rose, 1998; Warżała, 2014). Also in other analyses it has been proven that European national - regional business cycles are characterised by an increased synchronicity in more developed countries of a currency union (Artis, and Hang, 1997; Barrios, and Lucio, 2003; Beine, Candelon, and Sekkat, 2003; Marelli, 2007).

\section{The notion, core and morphology of business cycles}

According to the definition of Z. Kowalczyk, cyclical fluctuations are specified as "... the changes in the economic activity of the society being expressed in its expansion or shrinking that activity around the line of trend" (Kowalczyk, 1982). Cyclical fluctuations with numerous differences have certain common features, separating them from other types of 
fluctuations. The fluctuations are a result of self-reinforcing internal mechanisms occurring in the scale of the whole economy and have a short- and mid-term character. Incremental and diminishing time changes of the basic macroeconomic units, separated by turning points, are of a relatively regular nature. The arrangements of subsequent incremental and diminishing cyclical fluctuations constitute a business cycle (Barczyk, 2004).

The most common definition of a business cycle occurring in the market economy has been compiled by A.F. Burns and W.C. Mitchell, according to which "a business cycle is a kind of set of fluctuations occurring in aggregates presenting an economic activity of nations, organising their manufacturing in enterprises. The cycles consist of periods of expansion, occurring at the same time in many economic activities, subsequent crises, slumps and revivals, which fuse with the stage of the next cycle" (Burns, and Mitchell, 1946). A.F. Burns' and W.C. Mitchell's definition was modified by I. Mintz, who partly adjusted it to contemporary conditions. According to her, the cycles of growth are regular fluctuations in aggregate economic activity. Cycles of economic revival consist of a period of a high rate of return occurring simultaneously in most economic activities as well as a subsequent period of a relatively low rate of return, leading to a stage of a high rate of growth of the next cycle (Mintz, 1972). According to I. Mintz, a business cycle consists of only two stages, therefore the periods of revival and expansion from a classical cycle according to the definition of A.F. Burns and W.C. Mitchell were replaced with an indication of the period of a high rate of return, and the periods of crisis and slump were replaced with a period of a relatively low rate of return.

The morphology of cyclical fluctuations specifies the construction and shape, but also the forms of cyclical processes being manifest. External aspects of fluctuations are described in source literature by means of morphological features, i.e. features specifying the shaping of turning points, the course of action of specific stages as well as full business cycles. The most commonly applied features describing cyclical processes are: the character of upper and lower turning points, the length of specific stages, the length of full cycles, their frequency, amplitude as well as the intensity of fluctuations, a symmetrical and a asymmetrical character of cycles, as well as their structure broken down by entities and time frame (Barczyk, and Lubiński, 2009).

Every business cycle is composed of two fundamental parts: turning points as well as stages. Turning points are elements opening specific stages. They allow for the placement in time of the beginning and end points of the occurrence of stages, but they also allow for researching other features of fluctuations. Based on the purposes they serve, turning points may be divided into two groups (Barczyk, and Lubiński, 2009):

- upper turning points specifying the moment of ending the period of prosperity and entering the period of slump,

- low turning points, specifying the moment of finishing the period of low activity and the entering of the economy into the period of an improvement of the business cycle. 
Assuming every business cycle is some kind of a time period placed between two turning points identical in character, one may conclude based on an analogy that a stage of the cycle is some period occurring between subsequent, different turning points (Stock, 1979). In line with that, a business cycle is built of two parts: a stage of economic growth (placed between a lower and an upper turning point) as well as stages of an economic slump (placed between an upper and a lower turning point). The differentiating of specific stages is determined by an accepted definition as well as a method of differentiating specific turns applied (Tichy, 1972).

A significant morphological feature characterising whole business cycles, but also their stages, is their length. It is assumed the length is indicated by periods occurring between specific turning points. Usually the length of a stage of a business cycle is identical to the time period between two subsequent extremes of the researched time order, different in character. If the turning points of fluctuations are specified by the crossovers of the estimated line of trend with empirical data, then the length of the stage is equal to the period indicated by two subsequent, thus defined, turning points. The length of the business cycle is equal to the duration of two differentiated, subsequent stages, i.e. the stage of growth and the stage of slump (Barczyk, 2004).

Other morphological traits of business cycles, such as the frequency of the cycle, the amplitude of stages and the cycle, shall not be the subject of detailed analyses in the compilation hereinbelow, due to an extensive scope of the research.

\section{Methodological bases of the research process}

In the group of indicators allowing for the differentiation of turning points of business cycles and the analysis of their main features, quarterly indices of the manufacturing dynamics of the sold production of industry at current prices (where an analogous quarter of the previous year $=100$ ). The sold production of industry is considered to be a basic measure of economic activity of industrial enterprises. The sold production of industry is a value expressed in base prices, i.e. without the VAT tax, excise tax, and in total with the worth of the obtained grants, i.e. specific grants for products - the products and services (GUS, 2019). The data assumed come from the database of the Main Statistical Office, from the Database of Local Data, and it is calculated in line with the recommendation of a European System of National and Regional Accounts - ESA 1995.

In the analyses, the concept of a cycle of variations together with the assumptions concerning the construction of such a cycle as well as its external features are discussed. The main asset of that concept of differentiating the fluctuations is the fact that to a relatively high degree, it responds to the theoretical hypotheses concerning contemporary business cycles, and the series of variations obtained as a result of its application demonstrate relatively evident 
turning points (Tichy, 1976). The cycles of variations are created by fluctuations occurring in time series, out of which seasonal and random fluctuations as well as the tendency of development have been eliminated. In cycles of variations the upper turning point (low) occurs at the moment in which the relation of value of statistical distribution cleared of insignificant variations and the trend in relation to the trend function estimated for an analogous moment assumes a maximum (minimum) value. The stages in cycles of variation are obtained through the analyses of time series, demonstrating the changes of a given phenomenon in time, which are conditioned by the activity of a confluence of primary and secondary causes. Therefore the values of the respective variables of a chronological series are a function of component series. A method of elimination is used to indicate the strength and direction of the activity of a given type of fluctuation in the researched time series (Barczyk, 2001-2002).

The first step of the analysis was the elimination of seasonal and random fluctuations, the smoothening of chronological series with movable averages adjusted multiple times by means of deseasonalising by the TRAMO-SEATS procedure. The procedure is used and recommended by Eurostat. A series containing the joint functioning of trend and cycle has been accepted for further analysis. Assuming that the researched series include an individual element, and are thus movable (Kruszka, 2009), it has been assumed that the cyclical element of the variable is the difference between its current value and the value of trend (weighted average of the past, current and future observations). The application of that method is commonly known as the Hodrick-Prescott filter, which allows for the differentiation in the assumed time series of a stochastic trend in the form of a development trend. The most important limitation of the mentioned filter is a required minimum value of the time series, which is subjected to such filtering. The recommended minimum number of observations is 32 (Mills, 2003). Time series used in the analysis meet the formal requirements to apply the Hodrick-Prescott filter. As a result of conducting the filtering, a series of values demonstrating a long-term development value in the form of differentiated cyclical fluctuations (i.e. variations of the trend) is demonstrated, serving as the basis for further analysis.

\section{An empirical analysis of the regional business cycles in Poland}

In the conducted analysis of the progression of business cycles in the Polish economy in the period between the first quarter of 2005 and the second quarter of 2019, practical assumptions concerning cycles of variations are made. It has been assumed contemporary cycles consist of two elements: turning points (upper and lower) as well as stages (growth and slump). A high (low) turning point occurs in a situation in which the value of that element of the series with the random changes, seasonal changes as well as a development tendency being removed, reaches the maximum (minimum) in relation to the estimated line of trend. The turning points 
must alternate (Barczyk et al., 2010). It has been assumed that the minimum length of the stage is three quarters. It means the minimum length of the cycle might be six quarters. Analysing the length of the respective cycles it has also been assumed that the quarter in which there is an upper turning point shall be counted as the stage of growth and the period in which the lower turning point has been separated shall belong to the downward stage. Based on the empirical results obtained, one may formulate conclusions concerning business cycles occurring in the Polish economy. In the analysed time series, there are visible cyclical fluctuations which constitute business cycles. The number of stages differentiated as well as their character depend on the assumed time period of the region analysed. Analysing the progression of cyclical fluctuations for a time series of the sold production of industry in the period of the first quarter of 2005 until the second quarter of 2019, one may conclude the existence of significant disproportions between Poland (the reference series) and its respective regions (figure 1). In the case of time series of the sold production of industry for the Polish economy as a whole, nine stages have been differentiated, and their sequence has allowed for the differentiation of three full business cycles. The length of the differentiated business cycles was between 7 and 16 quarters.

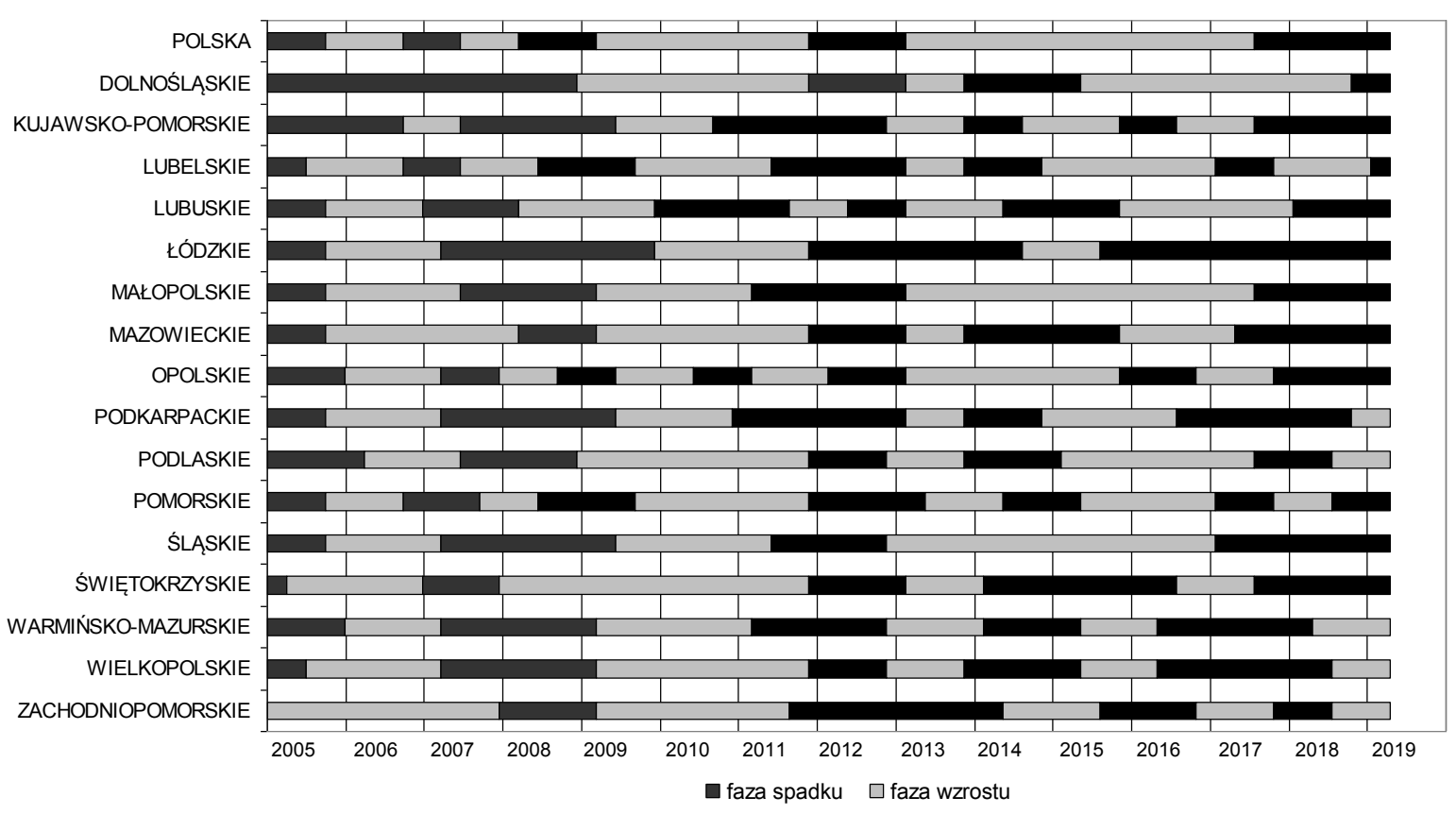

Figure 1. The indication of the stages of slump and the stages of growth in the period between the first quarter of 2005 and the second quarter of 2019. Source: own compilation based on the research conducted.

The first of the business cycles differentiated for the Polish economy lasted from the fourth quarter 2005 until the second quarter of 2007 and it was a cycle with a prevalence of the length of the stage of growth. From the standpoint of the economy of the whole Poland, the period of the last economic crisis became manifest with the highest fall in the first quarter of 2009 . As a result, in the second quarter of 2009, there was a "rebound," opening the last differentiated business cycle which lasted until the first quarter of 2013. The cycle was characterised by 
a siginificantly longer period of its duration (16 quarters), with a decisive advantage of the growth stage. The second cycle, in the period between the third quarter of 2007 and the first quarter of 2009, was convergent with the first cycle when it comes to duration (7 quarters), however with a prevalence of the duration of the slump stage.

What is noteworthy is the period between the second quarter of 2013 until the third quarter of 2017 - being the longest differentiated stage in the researched series for the economy of Poland. The growth stage has not, however, become part of the full business cycle, as the subsequent slump stage from the fourth quarter 2017 onwards has still been ongoing, as a result of which one may not separate the period as a full business cycle.

The case is similar in the following provinces: mazowieckie, świętokrzyskie and zachodniopomorskie - three full business cycles have been differentiated. Four provinces (dolnośląskie, łódzkie, małopolskie i śląskie) were characterised by a smaller number of differentiated stages of growth and slump - as a result, in the analysed period, we may be speaking about two full business cycles in those cases. The highest number of Polish regions, as many as six provinces, were characterised by four business cycles (kujawsko-pomorskie, lubuskie, podkarpackie, podlaskie, warmińsko-mazurskie, wielkopolskie). In lubelskie, opolskie and pomorskie provinces, there have been significantly shorter periods of growth and/or slump which in the analysed period composed five business cycles.

In the analysed progression of business cycle fluctuations in all Polish provinces, what was noticeable was their differentiation in terms of the occurrence of the beginning of a worldwide slump as well as the period of a progression from a slump period to a growth period. The łódzkie province entered the stage of growth with a relatively highest delay in relation to the reference series. Despite a siginificant variability and noticeable differences in the shaping of stages and business cycles in Poland as well as in the respective provinces, an interesting phenomenon also shapes the indicator of the sold production of industry in 2012, and especially in the third and fourth quarter - then in all researched entities, there was a stage of slump. It is the only period in the analysed period characterised by a high degree of compliance in the course of business cycles of all researched entities.

The matter of synchronising business cycles of the respective regions of Poland with the cycle for Poland as a whole is very important from the standpoint of the results of research obtained. After separating the turning points as well as the stages of business cycles of all researched entities, the level of their synchronisation towards a series of the sold production of industry for Poland as a whole was specified.

The recursive correlation coefficient has been used for that. Within the scope of a correlational analysis, the strength of the correlation of the cyclical changes between the economy of the whole state (a referential series), and its respective regions, was measured. In the empirical analysis of the synchronisation of cyclical fluctuations of the researched entities it has been assumed that the most important morphological features conditioning the level of 
their convergence shall be: moments of the occurrence of turning points, the length of the growth stage and the slump stage as well as the duration of the whole cycle.

Researching the level of the synchronisation of the business cycle in Poland with its respective regions in the researched period, one may conclude the level of convergence of the cycles was on average positive (table 1). In the figure, provinces have been arranged according to the criterion of the level of synchronisation.

\section{Table 1.}

The level of convergence of business cycles on the level of provinces with the business cycle of Poland as a whole in the period of the first quarter of 2005 and the second quarter of 2019

\begin{tabular}{|l|r|l|r|}
\hline \multicolumn{1}{|c|}{ Time series } & $\begin{array}{c}\text { The level of } \\
\text { convergence }\end{array}$ & \multicolumn{1}{c|}{ Time series } & $\begin{array}{c}\text { The level of } \\
\text { convergence }\end{array}$ \\
\hline MALOPOLSKIE & $\mathbf{0 . 8 7 6 7}$ & DOLNOŚLACKIE & 0.7791 \\
\hline POMORSKIE & $\mathbf{0 . 8 6 4 1}$ & WARMINSO-MAZURSKIE & 0.7761 \\
\hline MAZOWIECKIE & $\mathbf{0 . 8 6 3 9}$ & ZACHODNIOPOMORSKIE & 0.7251 \\
\hline WIELKOPOLSKIE & $\mathbf{0 . 8 5 7 3}$ & SAIETOKRZYSKIE & 0.6967 \\
\hline PODKARPACKIE & 0.8295 & KUJAWSKO-POMORSKIE & $\mathbf{0 . 6 4 3 1}$ \\
\hline LÓDZKIE & 0.8155 & PODLASKIE & $\mathbf{0 . 5 1 8 7}$ \\
\hline ŚLA_SKIE & 0.8143 & OPOLSKIE & $\mathbf{0 . 4 0 9 7}$ \\
\hline LUBELSKIE & 0.7849 & LUBUSKIE & $\mathbf{0 . 0 0 8 8}$ \\
\hline
\end{tabular}

Source: own compilation based on a research conducted.

Based on the amount of the researched entities, a division of provinces was made and two groups of regions were graphically presented. The first group consists of four regions whose cycle indicates the highest convergence with the business cycle of Poland (figure 2) growing in time.

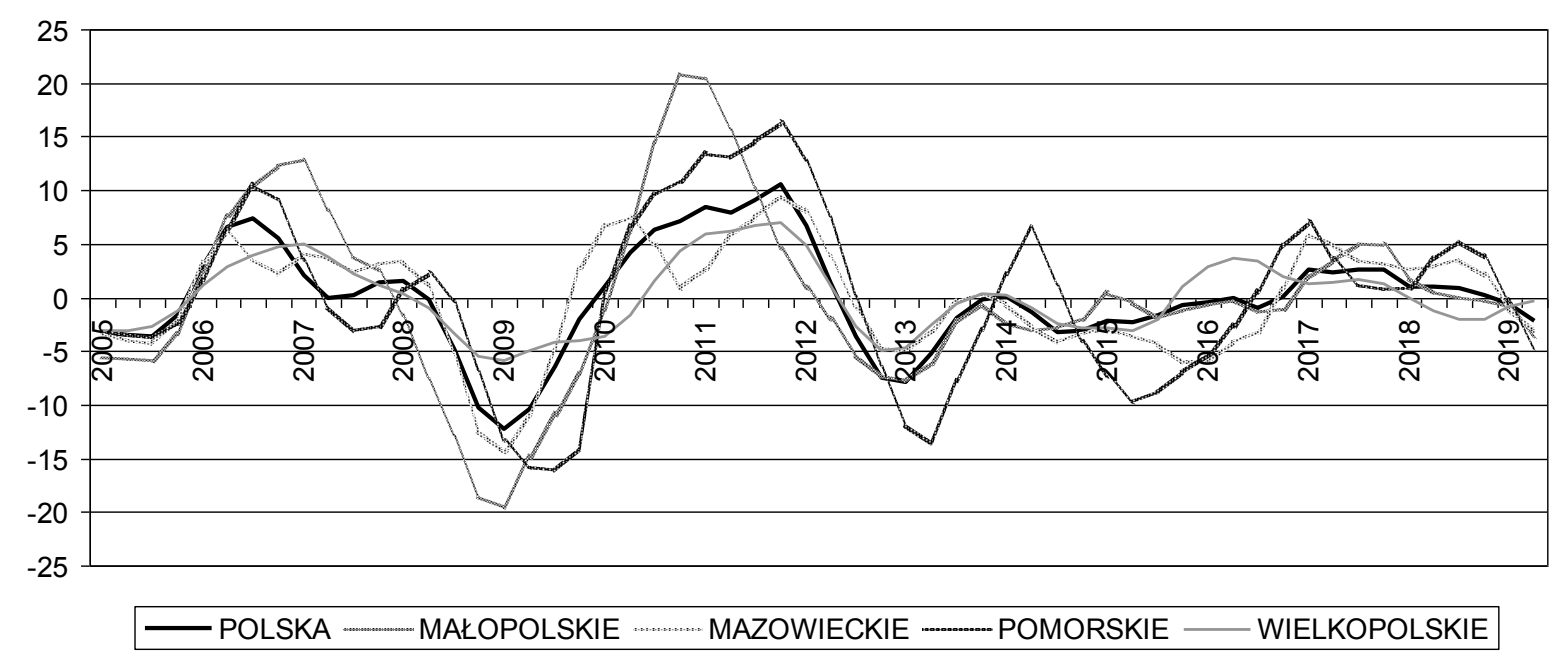

Figure 2. The progression of cyclical fluctuations for a time series of the sold production of industry in the period of the first quarter of 2005 until the second quarter of 2019 for Poland and the regions of the highest coefficient of synchronisation. Source: own compilation based on the research conducted.

The coefficient of recursive correlation of those entities is very approximate and falls into the category of between $0.8573-0.8767$. In the researched period, the highest rate of synchronisation with the business cycle of the Polish economy as a whole concerned the małopolskie province. Subsequently, the significant synchronisation of the cycles of regions 
with the reference cycle characterised the pomorskie and mazowieckie provinces. An insignificantly lower coefficient concerned the wielkopolskie province. A high coefficient of synchronisation of the regions might attest to their higher immunity to potential economic shocks. An important remark might be the fact that the mazowieckie and wielkopolskie provinces are the biggest regions in terms of the area of Poland.

What stems from the calculations and analyses, the four provinces enumerated are characterised by a wide spectrum of the manufacturing of products. Together with the śląskie and dolnośląskie province, they assume the leading positions in the structure of the production of industry sold in the period between the first quarter of 2005 and the second quarter of 2019 (figure 3 ). The provinces the most synchronised indicated in figure 2 comprise $45.05 \%$ of the structure of the sold production of industry in the analysed period. Moreover, those are also regions of a relatively large share in the GDP of Poland, thus they have a significant share in the progression of the fluctuations of the business cycle in total. Interpreting the results of empirical analyses, one may assume those are regions of a high economic potential.

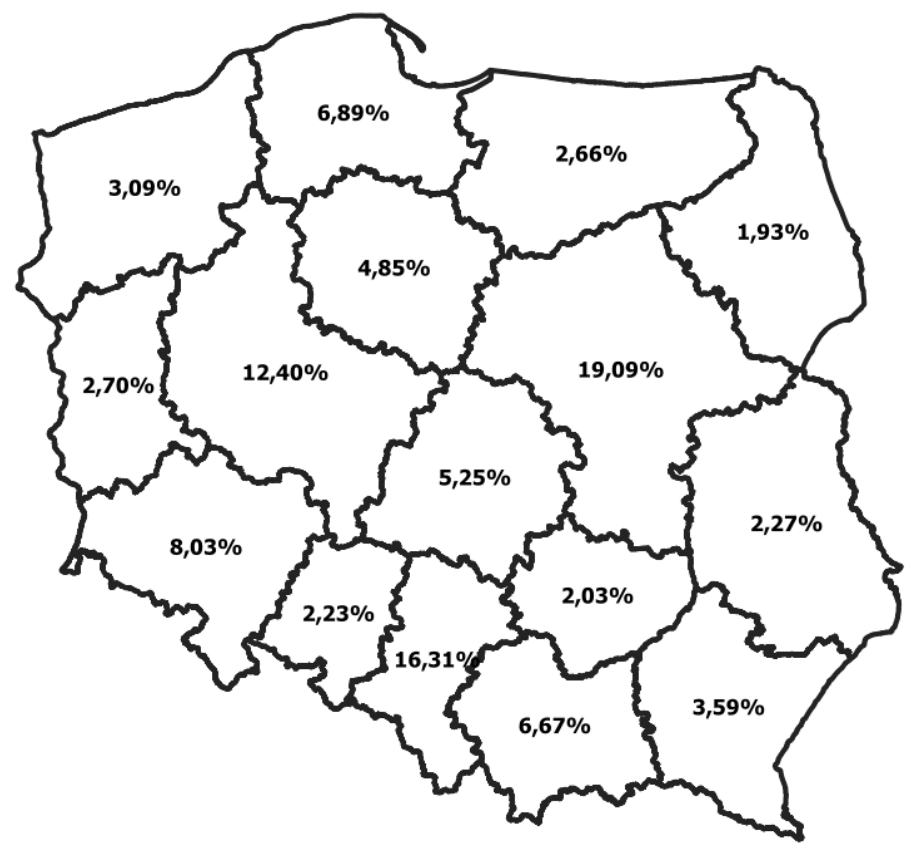

Figure 3. The structure of the sold production of industry in the regions of Poland in the period between the first quarter of 2005 and the second quarter of 2019. Source: own compilation based on the research conducted.

The second group consists of four regions, characterised by the lowest level of convergence in relation to the national cycle (figure 4). In the group (structuring from the lowest coefficient), the following provinces have been found: lubuskie, opolskie, podlaskie i kujawsko-pomorskie. The correlation coefficients of those regions have been included in the range between 0.0088-0.6431.

The most divergent coefficient of synchronisation with the reference series concerns the lubuskie province, which in the researched period levelled up at 0.0088 . The asymmetry in the progression of that cycle concerned mainly the periods of the third quarter of 2007 until the 
second quarter of 2012 as well as the fourth quarter of 2013 until the second quarter of 2018. Since the third quarter of 2018, both the Polish economy as a whole and the lubuskie province have entered the stage of the economic slump.

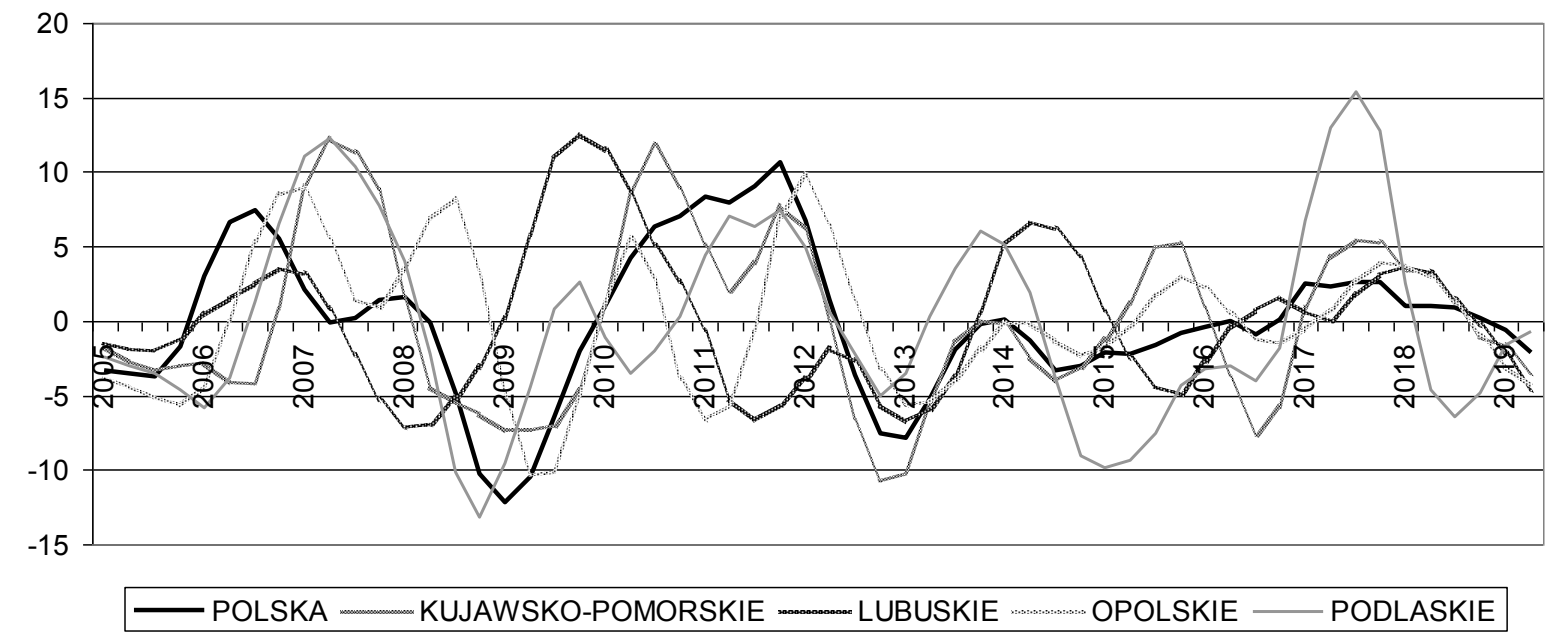

Figure 4. The progression of cyclical fluctuations for a time series of the sold production of industry in the period of the first quarter of 2005 until the second quarter of 2019 for Poland and the regions of the lowest coefficient synchronisation. Źródło: opracowanie własne na podstawie przeprowadzonego badania.

The sum total of the share of the sold production of industry in the group of four regions the least synchronised with the national cycle amounted to $11.71 \%$ (figure 3 ). It is a significant disproportion in relation to provinces highly correlated with the progression of fluctuations in the economy of Poland as a whole. The discrepancies in the shaping of the business cycle in the respective regions might to a large extent stem from the delays and accelerations occurring in the economy. Such a state of affairs might also be backed up by arguments relating to a relatively unvaried structure of the regional economy. The phenomenon of desynchronisation of cyclical fluctuations in the regional aspect might bring about the creation of asymmetrical shocks. In practice it might mean the deepening of the downward stage in regions touched by the economic crisis.

\section{Summary}

The variability of the progression of business cycles created the need for monitoring the rates of business cycles not only on the level of a given state, but also its regions. It has a significant importance within the scope of managing a regional policy stimulating a unified development. The knowledge of the specificity of business cycle fluctuations allows for proper reacting to the changes in the level of economic activity in the regions. Moreover, the publishing of information within the scope of the current state of the business cycle of 
a given area should render the economic policy conducted at the level of regions more credible, at the same time contributing to the increase in the significance of a region as the place of the future location of investment undertakings.

Making an assessment of the progression of business cycle fluctuations of the economy of Poland as a whole as well as business cycle fluctuations of Polish provinces in the period between the first quarter 2005 and the second quarter of 2019, one may conclude the progression is not uniform. The variation depends to a large extent on the specificity of development of each region. Provinces which have a lower share in the national structure of the sold production of industry demonstrate higher sensitivity to economic shocks. Very often those are smaller provinces in terms of the area.

Analysing and assessing the level of synchronisation of the respective regions, one ought to take into account delays and acceleration occurring in the economy. The highest degree of compliance with the national cycle has been demonstrated in provinces with the highest rate of share in the structure of the sold production of industry. Stimulating the economic growth, they contribute to the development of the region as well as the whole economy. It supports the hypothesis stated in the thesis assuming that the most synchronised with the cycle of Poland are regions having the highest share in the sold production of industry. The interpretations stemming from such theoretical and empirical analyses might be of significance and they constitute the basis for stating the goals and tools of the policy of stability. A proper application of the existing analytical tools is a condition allowing for the understanding of the mechanism of cyclical fluctuations. Applying proper instruments at a given stage of the business cycle might prevent unfavourable phenomena in the economy of the region, or be conducive to the stimulation of its growth.

The issue of differentiating between the effects of cyclical changes on the level of regions seems to be extremely important in the economic practice. The abovementioned considerations, the conducted research, as well as the obtained results might thus be a basis for taking up more extensive analyses in that field, comprising a discussion on the remaining morphological features of business cycles.

\section{References}

1. Artis, M., and Zhang, W. (1997). International Business Cycles and the ERM: Is there a European Business Cycle? International Journal of Finance and Economics, 2(1), 1-16. doi: 10.1002/(SICI)1099-1158(199701) 2:1<1::AID-IJFE31>3.0.CO;2-7.

2. Barczyk, R. (2001-2002). Metodologiczne problemy diagnozowania współczesnych wahań koniunkturalnych. Polityka Gospodarcza, 5-6, 43-58. 
3. Barczyk, R. (2004). Teoria i praktyka polityki antycyklicznej. Poznań: Wydawnictwo Akademii Ekonomicznej.

4. Barczyk, R., and Lubiński, M. (2009). Dylematy stabilizowania koniunktury. Poznań: Wydawnictwo Uniwersytetu Ekonomicznego.

5. Barczyk, R., Konopczak, K., Lubiński, M., and Marczewski, K. (2010). Synchronizacja wahań koniunkturalnych. Mechanizmy $i$ konsekwencje. Poznań: Wydawnictwo Uniwersytetu Ekonomicznego.

6. Barrios, S., and Lucio, J. (2003). Economic Integration and Regional Business Cycles: Evidence from the Iberian Regions. Oxford Bulletin of Economic and Statistics, 65(4), 497-515. doi: 10.1111/1468-0084.t01-2-00059.

7. Beine, M., Candelon, B., and Sekkat, K. (2003). EMU membership and business cycle phases in Europe: Markov-switching VAR analysis. Journal of Economic Integration, 18, 214-242. doi: 10.11130/jei.2003.18.1.214.

8. Camacho, M., Perez-Quiros, G., and Saiz, L. (2008). Do European Business Cycles Look Like One? Journal of Economic Dynamics and Control, 32(7), 2165-2190. doi: 10.1016/ j.jedc.2007.09.018.

9. Frankel, J., and Rose, A.K. (1998). The Endogenity of Optimum Currency Area Criteria. Economic Journal, 108(449), 1009-1025. doi: 10.1111/1468-0297.00327.

10. GUS [the Polish Main Statistical Office], Concepts used in official statistics. Retrieved from https://stat.gov.pl/metainformacje/slownik-pojec/pojecia-stosowane-w-statystycepublicznej/362,pojecie.html, 30.09.2019.

11. Kowalczyk, Z. (1982). Wahania koniunkturalne w gospodarce kapitalistycznej. In: Z. Kowalczyk (Eds.), Koniunktura gospodarcza. Warszawa: PWN.

12. Krugman, P. (1991). Increasing returns and economic geography. Journal of Political Economy, 99, 483-499. doi: 10.1086/261763.

13. Krugman, P. (1993). Lessons of Massachusetts for EMU. In: F. Torres, and F. Giavazzi (Eds.), Adjustment and Growth in the European Monetary Union (pp. 242-244). Cambridge: CEPR and Cambridge University Press.

14. Kruszka, M. (2009). Synchronizacja wahań koniunkturalnych w krajach wysokorozwiniętych oraz państwach okresu transformacji. Zeszyty Naukowe Uniwersytetu Ekonomicznego w Poznaniu, 115, 193-215.

15. Marelli, E. (2007). Specialisation and Convergence of European Regions. The European Journal of Comparative Economics, 4(2), 149-178.

16. Mills, T.C. (2003). Modeling Trends and Cycles in Economic Time Series. London: Palgrave Macmillan.

17. Mintz, I. (1972). Dating American Growth Cycles. In: V. Zarnowitz (Eds.), Economic Research: Retrospect and Prospect, 1, The Business Cycle Today (pp. 39-88). Cambridge: NBER. 
18. Niemira, M.P., and Klein, P.A. (1994). Forecasting Financial and Economic Cycles. New York: John Wiley \& Sons.

19. Spychała, J. (2015). Ocena cech morfologicznych wahań cyklicznych w Polsce w latach 2001-2013. Prace Naukowe Uniwersytetu Ekonomicznego we Wrocławiu. Ekonomia, 401, 452-461. doi: 10.15611/pn.2015.401.41.

20. Stock, K. (1979). Verfahren zur statistischen Analyse zyklischer Schwankungen. IFO Schnelldienst, 35-36.

21. Tichy, G.J. (1972). Indikatoren der österreichischen Konjunktur. Wien: Österreichisches Institut für Wirtschaftsforschung.

22. Warżała, R. (2014). Regionalne cykle koniunkturalne w Polsce w latach 2000-2014. Zeszyty Naukowe Uniwersytetu Szczecińskiego. Studia i Prace Wydziału Nauk Ekonomicznych i Zarzadzania, 35(t. 2), 529-550.

23. Warżała, R. (2016). Cykle koniunkturalne w polskich regionach. Studium teoretycznoempiryczne. Olsztyn: Wydawnictwo Uniwersytetu Warmińsko-Mazurskiego. 